\title{
The Fragmented Island: Ethnic Conflict and the Politics of Culture in Sri Lanka
}

\author{
Sujata Ramachandran
}

This article examines the role of culture in the ethnic conflict and strife in Sri Lanka. The general aim is to achieve an understanding of the nationalist process, the force of nationalist ideas and traditions in motivating action-action that is often violent and intolerant-and to demonstrate the value of a cultural approach to the understanding of modern societies. Culture has been examined in two ways here, namely, the dramaturgic approach to culture which emphasizes the expressive dimensions of culture, and the politics of culture or the political culture approach, whereby cultural manifestations are utilized effectively to maintain power between groups. The article concludes that the SinhaleseTamil conflict is a product of modern politics, and culture has been used effectively to legitimate rival nationalisms in Sri Lanka.

\section{Introduction}

For nearly a decade, the island of Sri Lanka hasbeen involved in the " continuing haemorrhage of a Lebanon-or-Ulster-style internecine civil war" (Wilson 1982, 295), where the Sinhalese majority and the Tamil minority are in violent conflict. This opposition is often portrayed as a product of ancient history or the outcome of animosity that has allegedly existed unchanged for centuries. The majority has turned to the elements of culture and cultural symbols, including religion, language and the historical past, to justify their actions of subordinating the minority. The Tamils eventually retaliated by engaging in a armed

Sujata Ramachandran, from New Delhi, India, has recently completed her postgraduate work at the Centre for South Asian Studies, University of Toronto. An earlier draft of this article was delivered at the centre's symposium in October 1992. revolutionary struggle for Tamil national liberation, demanding the creation of a separate state of Tamil Eelam.

The role of culture and its effectiveness in legitimizing the rival nationalisms in Sri Lanka remains largely unacknowledged. This article attempts to examine the function or the politics of culture in this ethnic conflict pertaining to the generation of opposing ethnic identities, the role of the historical past, political myths and elite/interest groups in symbolic construction, and the meanings these provide for the groups in question.

\section{The Culture of Nationalism and the} Politics of Culture

To inquire into the truth of the political myths is, therefore as meaningless and ridiculous as to ask for the truth of the machine gun or a fighter plane. Both are weapons and weapons prove their truth by their efficiency. If political myths could stand this test they need no other or better proof. In this respect, the theory was beyond attack and invulnerable. All it had to do was to put the political myths into action and to show their constructive and destructive power.

$$
\begin{aligned}
& \text { - Ernst Cassirer, "Judaism and } \\
& \text { Modern Political Myths" }
\end{aligned}
$$

Culture has assumed a place of pride in the litany of nationalisms everywhere. Almost universally the culture that nationalists worship include the founding myths, legends, customs, traditions and language of the nation. These are at once constituted within the nation and constitute the nation. They are integral to national sovereignty and are made sacred in the nation as the nation is made sacred in them. Culture in nationalism becomes an object, a reified thing, something that can be separated or abstracted from the flow of social life. Made into a religious object, culture becomes the focus of de- votion. It can have the character of a religious fetish, an idol, a thing that has selfcontained magical properties (Kapferer $1988,4)$.

Culture in nationalism becomes the focus of this article and is seen in a particular way here. The dramaturgic approach has been adopted relating to the expressive or communicative properties of culture (Wuthnow 1987,13). Culture is identifiable as the symbolic-expressive dimension of social culture and social relations that communicates information about morally binding obligations and is, in turn, influenced by the structure of these obligations. Culture, in this approach, consists of utterances, acts, objects and events_all of which are observable. What is significant is the capacity of the various elements of culture, including rituals, ideologies and other symbolic acts, to dramatize the nature of social relations. Symbolic acts are likely to be meaningful if they articulate the nature of social relations.

Political culture "consists of the system of empirical beliefs, expressive symbols, and values which defines the situation in which political action takes place" (Pye and Verba 1965, 9). In this article, I refer to the importance of politics as an independent variable shaping ethnicity, one that pits ethnic entities against one another and offers ethnic entrepreneurs high incentive for the cultural mobilization of their groups. Ethnicity has been highly politicized in Sri Lanka, and cultural mobilization is used effectively in the competitive pursuit of wealth, status or power. Political culture refers not to what is happening in the world of politics and society per se, but what peoplebelieve about these happenings. And these beliefs can be of several kinds: they can be empirical beliefs about the actual state of political and social life; they can be beliefs as to the goals

Refuge, Vol. 13, No. 3 (June 1993) 
and values that ought to be pursued; and they may have an important expressive and emotional dimension. People respond to what they perceive of politics and its use of culture and they interpret what they see. From the cultural point of view, for instance, we would look at these events in the political history of Sri Lanka, not so much as a series of objective events but as a series of events that may be interpreted quite differently by different people, and whose effects on future events depend on theirinterpretations. The terms, "meaning" and "interpretation", here, are relational terms. They refer to the interaction between what exists in the mind of the individual or collectivity and to what happens in the outside world.

Ethnic conflict is, therefore, related primarily and sometimes solely to the problems of social organization that are conceived in terms of politics and the allocation of scarce resources. More specifically, ethnicity is said to be inherently related to competition and conflict. Ethnic actions are actions in which a claim to common provenance (or origin), ancestry or culture are potent (Shlomo 1974, 281-84). In the case of Sri Lanka, ethniccultural symbols are activated or manipulated in the framework of political conflict.

Who Is a Tamil? Who Is a Sinhalese? The Question of Collective Identity

All nice people like Us, are We, And everybody else is They.

$$
\text { - Rudyard Kipling }
$$

The emergent nationalities in Sri Lanka indicate the tendency of individuals to identify with particular collectivesor ethnic groups such as Tamils or Sinhalese. This is based on the principle of inclusion or exclusion (Breton 1988, 1992). These include the conditions for becoming or ceasing to be a member; and the circumstances under which one can be expelled (Breton 1992, 4). Identity is a subjective, individual phenomenon; it is shaped through the constantly recurring question, "Who am I?" with the inevitable corollary, "Who is he?" or "Who is she?" Generalized to the collectivity, these become, "Who are we?" and "Who are they?" These questions involve the basic processes of cognition, perception and symbol formation. This identity can be an individual phenomena, but is also applicable within the social grouping to which the individual belongs. Indeed, identity "is a process located in the core of the individual and yet also in the core of his communal culture: a process which establishes, in fact, the identity of these two identities" (Young 1976, 20).

The basis of these solidarity groupings are commonalities or affinities of ethnicity, language, race, caste, assumed blood tie, custom and/or territory (Young 1976, 12). The main formal criterion of membership of the rival Sinhalese and Tamil collectivities today appear to be linguistic, religious and historical antecedents. Although four different ethno-religious-linguistic collectivities reside in Sri Lanka, more than 92 percent of the inhabitants identify themselves with one of the two distinct groups, Sinhalese and Tamil. In 1981, the estimated population of the island was 14.85 million, of which the Sinhalese and Tamil communities account for 74 and 18.2 percent, respectively. The Tamils themselves have been divided into Sri Lankan Tamils and Indian Tamils which form 12.6 and 5.5 percent of the total population, respectively. The other group, i.e., the Muslims (Moors) form 7.1 percent of the total population. The last three categories are all speakers of Tamil, but are differentiated by religion and/or putative origin. Indigenous Sri Lankan (Ceylon) Tamils are settled in the north and the east; Indian Tamils are the descendants of estate workers brought in from South India during the British period (Spencer 1990, 14). [Also see Manogaran in this issue ]

Of importance in the long run is how the political identities of the Sinhalese and Tamils came into being, how these groups came to represent the differences themselves, and how these ideas were used. Today these ideas about "Sinhalaness" centre around four themes:

- The Sinhalese share a certain biological nature; that they are a race. The unity of the Sinhalese is asserted over and above Low Country/Up Country or caste differences. Indeed, the
1981 census was the first to treat Sinhala as a unity. Although respondents had been classified in separate Up Country and Low Country categories by the enumerators, this division was not maintained in the published records. Interestingly, no such unification of the Tamil population was effected in this census.

- One manifestation of this biological community is the sharing of a common language.

- "True Sinhalese" also share a common religion:i.e., they are Buddhists.

- Sri Lanka is in its entirety the land of Sinhala and of Buddhism: it is the Sinhalese-Buddhist nation. The people, language, religion, culture and territory are all intimately linked.

These ideas are paralleled among the Tamil community (Nissan and Stirrat 1990, 30).

The groups involved here are not necessarily permanent, frozen collectivities, but are in a state of flux in response to long-term forces of social change and shorter-term alterations in political context. For example, the Sinhalese themselves were a divided group not long ago and the development of a common Sinhalese identity took time. In the 1920s, there was still a sizable number of Kandyan Sinhalese who demanded separate representation from Low-Country Sinhalese and who also favoured a federal system of government (Nissan and Stirrat 1990, 45). Similarly, the Tamils themselves were divided into the Sri Lankan Tamils and Indian Tamils, as described earlier. But Tamil and Sinhalese nationalisms today tend to overlook these differences.

The main criterion of membership of the rival Sinhalese and Tamil communities today is linguistic, but in the colonial period the most salient identities-at least as far as riots and disturbances were concerned-were religious. Catholics, who were pitted against the Buddhists and Hindus in colonial conflicts, are now divided into Sinhalese Catholics and Tamil Catholics. Yet Muslims, who are predominantly Tamil-speaking and as 
such might to be thought to have suffered as much as anyone from linguistic discrimination since 1956, have stubbornly maintained their ethnic separateness from their fellow Tamil speakers and have pursued their own political course in recent years while remaining aloof until very recently from the central ethnic conflict. In fact, the particular assembly of "races" identified in the census of Sri Lanka, based on the mélange of religious, linguistic and geographical criteria, can only be explained through a detailed account of the politics of identity (Spencer 1990, 8).

\section{The Power of the Past}

The use of history is no longer incidental with interesting snippets being taken to bolster an argument, but it is fashioned and streamlined to serve a purpose, and contradictory details are blacked out. - Anon

Sinhalese and Tamil communities in Sri Lanka tend to view their relationships in terms of histories that stretch back for at least 2,500 years. These histories buttress the opposing territorial claims of the two communities and make the conflict between them seem inevitable. For the Sinhalese, history justifies their claim to impose their rule all over Sri Lanka. For Tamils, too, history is used to justify demands, in the past for a degree of autonomy in Tamil-dominated areas, and today for total separation from the Sinhalese-dominated parts of the country (Nissan and Stirrat 1990, 19). Histori$\mathrm{cal}$ myths and legends are recreated to reinforce the idea. Just as the Sinhalese Buddhist ethnic majority seeks to review the past in modern garments, so the Tamil minority in its turn has begun to take refuge in the fact that in Ceylon there was once a separate Tamil kingdom (Wilson 1988, 22).

The Sinhalese people claim that even if they were not the first inhabitants of the island, a status they allow to the "primitive Veddas," they were at least the first "civilized" settlers of Sri Lanka (Nissan and Stirrat 1990). They claim to be descended from north Indian Aryan ancestors who spoke an Indo-European language that developec into Sinhala. Prince Vijaya, the mythical ancestor of the Sinhalese people, and his followers are said to have arrived on the shores of Lanka on the day of Buddha's death; but even before Vijaya's arrival, Lanka claims to have had a close relationship with the Buddha. According to the island's ancient chronicle histories, the Buddha visited the island on several occasions and announced that in Lanka his "doctrine should ... shine in glory" (Nissan and Stirrat 1990, 20). However, the Sinhalese were only converted to Buddhism in the third century B.C. by Mahinda, son of the great Indian emperor, Ashoka, during the reign of King Devanampiyatissa. Since then, so it is claimed, they have with few exceptions always been Buddhist. During the Anuradhapura period (circa third century B.C. to ninth century A.D.), a great Buddhist civilization flourished in Sri Lanka. This state was continually under habitants of Lanka were really Tamil; that the Sinhalese were originally Tamil who converted to Buddhism and adopted Sinhala, a language based on Pali, the language of Buddhist texts; and much of what the Sinhalese uphold as monuments of their past greatness was actually produced by Tamil ancestry.

The historical arguments are numerous, but as it is the Sinhalese who are politically and numerically dominant in the island, so it is Sinhalese history, to a great extent, that sets the terms of the debate. Despite the fact that these two histories are opposing versions of the past, each stressing the claims of the community that generatesit, they share many features in common. Both present the past in terms of the interaction of two opposed entities, the Sinhalese and Tamils, who have always been as separate as they are today. Secondly, they

\section{Despite the fact that these two histories are opposing versions of the past, each stressing the claims of the community that generates it, they share many features in common.}

pressure from the South Indian kings; one in particular, Elara, ruled Anuradhapura for over forty years in the second century B.C. until he was defeated by the heroic Sinhalese-Buddhist king, Dutugamunu. Eventually, the Sinhalese were forced to retreat southwards, first to Polonnaruwa, then to various other capitals until the last phase of Sinhalese independence, which centred on Kandy. The Kandyan kingdom was eventually ceded to the British in 1815. The Sinhalese claim is that these Tamil communities never, or only rarely, formed separate political entities. Rather, once settled in Lanka they accepted the suzerainty of the Sinhalese kings (Nissan and Stirrat 1990, 20).

Not surprisingly, the Tamil version of the past is somewhat different (Nissan and Stirrat 1990). In its "soft" version, it is argued, Tamils have lived in Sri Lanka for at least 2,000 years (from the Elara period) and formed their own autonomous political units independent of Sinhalese control. Satchi Ponnambalam, for example, claims that the original in- consist of arguments over events that allegedly occurred between the fourth century B.C. and the tenth century A.D. Thirdly, they present the two communities as historically and continuously opposed through warfare, joining an ancient past to the present with no regard for the hiatus of centuries. Fourthly, the histories are both concerned with a "national people's" claim to its own territory. Finally, each side presents the other as little more than barbarians (Nissan and Stirrat 1990). Both sides in the present political context back up their respective claims through the selective and competitive use of archaeological evidence. Factions on each side have been willing to destroy or reinterpret evidence that would support the other party. Differing maps are produced that purport to show the distribution of Sinhalese and Tamils in Lanka in the past. In this context S.J. Tambiah writes:

Although the major identity component of the Sinhalese are theirSinhalese language and Buddhist religion, and of the Tamils, their Hindu religion, 
both these populations share many parallel features of traditional caste, kinship, popular religious cult, customs and so on. But they have come to bedivided by theirmythiccharters and tendentious historical understanding of their past (Tambiah 1986, 5).

Another aspect that has been conveniently overlooked is that the Tamil and Sinhalese identities are largely created since "it seems that neither the Sinhalese nor the Tamils have remained racially pure" (De Silva et al. 1988, 13), and that intermixing has taken place, as revealed by the following statement:

Aside from its plethora of faiths, Sri Lanka is also a country of racial diversity revealed in the frequency of eyes coloured from brown to blue, crinkly and smooth hair, flat and hooked noses. Proof enough that no racial stockhasescaped mixture with several others (Ram 1989, 31).

\section{Power Relations and Symbolic Action: The Role of "Political Myths"}

But meanings and symbols are not dependent on things as context; they are relations, not objects. Ignoring this point, seeing meanings and symbols as things, has allowed cultural analysts to erect a distinction between symbolic structures and concrete structures; to differentiate religion, myth, art-held to be "essentially" symbolic forms-from economics, politics, kinship, or everyday living. This is a position we reject.

- Dolgin et al. quoted in Gusfield and Michalowicz 1984.

The myth, an unquestioned belief held in common by a large group of people that gives events and actions a particular meaning, is a particularly relevant form of symbol in the emergence of mass political movements. When we recognize the functions it serves for the group and its individual adherents, we can define the systematic ties between individual role attachment and common adherence to a controversial political movement (Edelman 1971, 53).

While myths or symbols exist in their own right and are observed for their intrinsic values, they are nearly always manipulated, consciously or unconsciously, in the struggle for and the maintenance of power between individuals and groups. Political myths or symbols have distinctive characteristics that make them dynamically different from other perceptions. They develop and are mutually reinforced by large collectivities of people, evoking intense hopes and fears, threats and reassurances (Edelman 1971, 2). In other words, myths and symbols are objects, acts, concepts or linguistic formations that stand ambiguously for a multiplicity of disparate meanings, evoke sentiments and emotions, and impel men to action (Cohen 1974, ix).

In the following discussion of symbolic forms, a distinction is thus made between the kinds of meanings. The denotation of symbolism is that it stands for something else, but the meanings derived from these symbols are not the same-they provide different meanings to different individuals or groups.

First, collectives generally have a "myth of origin" that entails the reconstruction of the past and/or creation of a mythical past. It includes views about the present's continuity or rupture with the past, as well as the expectations and/ or desiderata for the future (Breton 1992, 6).Two significant dimensions of the past include the symbolically constructed past in which the past is the overflow of the present. It is oriented from the present. It is akin on one side to our escape fancies, those in which we rebuild the world according to our heart's desires, and on the other to the selection of what is significant that must be held or reconstructed. Its decisive character pushes back conditioning continuities of the present (Maines et al. 1983, 163). The other dimension includes the "mythical past," which refers solely to symbolic creations that are used to manipulate social relationships. These pasts are creations rather than re-creations because they are not empirically grounded. They are fictitious. However, they are empiri$\mathrm{cal}$ in their consequences because they can materially affect relationships (Maines et al. 1983, 164). In Sri Lanka, the myths of origin form the complex of the above and can be conceived as purposeful creations which control and shape collective behaviour. They provide a manipulative dimension to social relations because they are created precisely for establishing and maintaining advantage. Cohen terms this "cultural extension," in which myth refers to some prior point in the society's history, the rooting of the present in the past and in so doing legitimizing the present by investing it with the values that have become sacred by their very historical or traditional nature.

The point has been made succinctly by Worsley, "Men ransack the past to find legitimations for the present: they discover precursors, trace intellectual pedigrees, rewrite history" (Cohen 1975, 15).

The great myth of origin of the Sinhalese people, as given in the religious chronicles, especially the Mahavamsa, of the foundation of their state and of the triumphant reconquest by a Sinhalese Buddhist king of Sri Lanka, creates a divinely sanctioned social order in which Sri Lanka becomes the land of the Sinhalese Buddhists and which legitimizes the right of the Sinhalese majority to subordinate the Tamil minority. The Buddhism of Sinhalese nationalism is one of nationalist practice and interpretation, a Buddhism reconstituted in the religion of nationalism. It creates the vision of a myth of symbiotic social order in which Tamils have a subordinate role and Sinhalese-Buddhists a superordinate one based on the divinely ordained order. It validates the dominant status of the Sinhalese and also convinces them of their "right" to their superior position in society.

On the other hand, detection of threats to the collectivity becomes a potent factor in cultural mobilization; anxieties andinsecurities dictate solidary responses. Crises engender acute anxieties and highly polarized perceptions. Not surprisingly, the Tamils denounce the established practice of Sinhalese nationalism and claim that this conflicts with the manner in which their members live or ought tolive. They feel that society frustrates their aspirations and denies them the kind of life they feel is rightly theirs. 
When cultural communities collectively perceive serious threats to communal status in the political environment, group solidarity tends to increase, as in the case of Tamils. Thus, counterstate of a nation of Tamils is created to prove their stake to the claim. They suggest collective course of action to allay their anxiety.

Thesignificance of the political myths is through their power to merge diverse perceptions and beliefs into a new and unified perspective that symbols affect what men want, what they do, and the identity they create for themselves (Edelman 1971, 6). Further, a political myth is always the myth of a particular mogeneous, highly potent or omnipotent group that conspires to harm the ingroup, i.e., the Sinhalese. The actions are dictated by fear, signed by distrust or executed by emotions. Each group has a generalized perception of the other, clothed in insecurity and hostility, which swiftly imputes aggressive and threatening intent and intense fervour in the response of the other to each stage of the unfolding crisis (Young 1976, 161).

A political myth tells the story of a political society; it is the story of a political society that was supposedly created in the past and that must now be restored or preserved. In reality, it concerns a political society destined to becreated in the

\section{In symbolic transformations such as those recounted earlier, the ethnic polarization of the present is defined in terms of past rivalries, and, in that process, the past itself is rearranged in terms of the policies of the present.}

group. It has as its hero not an individual but a tribe, a race, a class, an ethnic group or collectivity, as in the case of Sri Lanka.

Evocation of the cultural map of reality depends on the reception of social cues that prompt this response. Very often, the cues are supplied by messagescommunication face to face or through interpersonal media-which have already processed reality through a cultural symbol system and transmit information in a communal structure (Young 1976, 143). Riots by Sinhalese thugs on Tamils and their property, making Sinhala the national language in the "Sinhala only" policy, disenfranchisement of the Indian Tamils, the use of a Sinhalesecultural symbol on the national flag-all these actions have different meanings for the different communities. The Tamils feel that the status and benefits due them are being denied or threatened. It also evokes the feeling that the superordinate group, the Sinhalese, in this case, maintain and enjoy the privileges unfairly or unjustly. On the other hand, the Sinhalese majority registers these actions as the expected order of things. For them, the out-group, the Tamils are perceived as a different, ho- future and it is told for the purpose of encouraging men to hasten its advent. Today, both Tamil and Sinhalese strive to create two different nations; Sinhalese nationalism attempts to establish Sinhalese hegemony on the entire island and Tamil nationalism demands the creation of a separate state of Tamil Eelam in the northern and eastern part of the island.

In symbolic transformations such as those recounted earlier, the ethnic polarization of the present is defined in terms of past rivalries, and, in that process, the past itself is rearranged in terms of the policies of the present. History/myth is of the past but not in that past; it is rooted and flourishes in the present.

Thus, political myths or metaphors create and filter value premises. These myths can be termed "political" because they serve as a means of establishing power relationships in society that are the basis of politics. The political myths highlight the benefits that flow from a course of action and erase its unfortunate concomitants, helping speakers and listeners to conceal disturbing implications from themselves. Ambiguous terms in a threatening context create a world in which painful, inconvenient facts are excluded, conveniently ignored and in which self-serving courses of action are justified. Because the myth is a means of succour against severe anxiety or vice versa, it is strongly embraced and defended, and in doing so becomes the mould into which perceptions of political developments are organized (Edelman 1971, 74). Political leaders can thus rely on the ubiquity of anxiety and its externalization in the myths as an ever present base for a following. By the same token, anxiety readily converts even implicit and metaphorical references to mythic themes into vivid and intensely held beliefs (Edelman 1971, 80).

\section{The Role of the Elite in Cultural Symbolic Constructions}

Cultural symbolic constructions can be conceived as being deliberately built by social and institutional elites and more or less successfully imposed on members. As such, they are part of the exercise of power through which elites maintain the institutional order of society or ethnic community and their place in it. The symbolic universe is thus consciously created from "above" (Breton 1992, 15). Interest groups like the elite exploit the symbolic forms to shape power relations in society. In this respect, the two orders, symbolic as manifestation of culture and political as relations of power between groups and/or individuals, are interdependent or to some extent causally related and imply a competition between groups for resources and/or power.

In the context of Sri Lanka, government leaders, politicians or even academics compose the important constituencies of mythic acceptance, infuse their rhetorics with references tolegends. The legends of the religious chronicles Dipavamsa and Mahavamsa, theirstories of origin, armed struggle and heroic resurgence, are woven into the fabric of Sinhalese religious and ritual life. The president of Sri Lanka, Ranasinghe Premadasa [who was assassinated on May 1, 1993] was popular among the urban and rural poor. He published a short novel in Sinhala and in English that presents the heroic progress of Dutugamunu. The tone of the novel 
aligned the president with widespread Sinhalese populist sentiment (Kapferer 1988, 42).

Publicevents are often the occasion of ideological recharging by politicians at all levels within the government. At the opening of a small deity shrine in Panadura, a town just south of Colombo, Cyril Matthew, then the minister of industries and scientific affairs, stated that "74 percent of the Sinhalese race should not be dominated by 12 percent of the minority community." At the same time, heannounced that nationals in Sri Lanka, whatever their community, had the right to live anywhere in Sri Lanka, and that " 300 Buddhist temples had been excavated by the archaeological department in the north and in the east." These areas are dominated by the Tamil minority. The program of the reclamation of temples was also announced on radio and television. Such statements are completely consistent with Sinhalese claims to territorial hegemony that are supported by a reading of the ancient chronicles. They are also consistent with schemes of Sinhalese colonization and resettlement and with the practice of building replicas of ancient monuments, such as the Ruwaveliseya of Dutugamunu, around the island (Kapferer 1988, 43).

Similarly, academics have been no exception to the rule. A scholar from Sri Lanka claimed that Sri Lanka or Sinhaladipa (Island of the Lion where the lion is a Sinhalese cultural symbol) is the land of the Sinhalese (People of the Lion) when she wrote:

Sri Lanka was the land of the Sinhalese and ... non-Sinhalese who resided there were allowed to do so by grace and favour of the Sinhalese "master race" who had prior rights of possession and were the exclusive sons of the soil (Tennekoon 1990, 216).

\section{Conclusion}

In Sri Lanka, both Sinhalese and Tamils are engaged in a modern battle fought with traditional slogans and/or weapons. Ethnicity and nationalism in this context are thus seen to be fundamentally, political phenomena as the sym- bols of the traditional culture are used to articulate political alignments and emerging ethnic cleavages. Cultural symbols, including history, lend significance to the collective violence of nationalism in Sri Lanka. But, the "myths" being used to legitimize the rival nationalism are being worked anew in the modern situation of ethnic conflict and relate to present political and social realities in Sri Lanka.

\section{References}

Barth, Frederick. 1969. Ethnic Groups and Boundaries. Boston: Little, Brown and Co.

Breton, Raymond. 1988. "From Ethnic to Civic Nationalism." Ethnic and Racial Studies 11: 85-102.

_ 1992. "Collective Dimensions of the Cultural Transformation of Ethnic Communities and the Larger Society." In Migration and the Transformation of Cultures, edited by Jean Bumet.

Cohen, Abner. 1974. Two Dimensional Man. London: Routledge \& Kegan Paul.

Cohen, Anthony P. 1975. The Management of Myths: The Politics of Legitimation in a Newfoundland Community. Manchester: Manchester University Press.

Daniel, Valentine E. 1990. “Afterword: Scared Places, ViolentSpaces." In SriLanka: History and Roots of Conflict, edited by Jonathan Spencer, 227-46. London: Routledge.

DeSilva C.R. 1982. "The Sinhalese-Tamil Rift in Sri Lanka." In The States of South Asia: The Problems of National Integration, edited by A.J. Wilson and D. Dalton, 155-74. New Delhi: Vikas.

De Silva, K.M. 1986. Managing Ethnic Tensions in Multi-Ethnic Societies: Sri Lanka 18801985. New York: University Press of America.

De Silva, K.M., Pensi Duke, Ellen Goldberg and Nathan Katz, eds. 1988. Ethnic Conflict in Buddhist Societies: Sri Lanka, Thailand and Burma. Boulder: Westview Press.

De Vos, George, and Lola Romannuci-Ross, eds. 1975. Ethnic Identity: Cultural Continuities and Change.Palo Alto: Mayfield Publishing.

Edelman, Murray. 1971. Politics as Symbolic Action: Mass Arousal and Quiescence. Chicago: Markham Publishing.

Gusfield, Joseph, and Jerzy Michalowicz. 1984. "Secular Symbolism: Studies in Ritual, Ceremony and the Symbolic Order in Modern Life." Annual Review of Sociology 10: 417-35.

Hellman-Rajanayagam, Dagmar. 1990. "The Politics of the Tamil Past." In Sri Lanka: History and Roots of Conflict, edited by Jonathan Spencer, 107-24.. London: Routledge.
Kapferer, Bruce. 1988. Legends of People: Myths of State. Washington: Smithsonian Institution Press.

Kemper, Steven. 1990. "J.R. Jeyawardene: Righteousness and Realpolitik." In Sri Lanka: History and Roots of Conflict, edited by Jonathan Spencer, 187-204. London: Routledge.

Maines, David R, Noreen Sufrue and Michael Katovich. 1983. "The Sociological Import of G.H. Mead's Theory of the Past." American Sociological Review 48: 161-73.

Manogaran, Chelvadurai. 1987. Ethnic Conflict and Reconciliation in Sri Lanka. Honolulu: University of Hawaii Press.

Nissan, Elizabeth and R.L. Stirrat. 1990. "The Generation of Communal Identities." In Sri Lanka: History and Roots of Conflict, edited by Jonathan Spencer, 19-44. London: Routledge.

Ponnambalam, Satchi. 1983. Sri Lanka: The National Question and the Tamil Liberation Struggle. London: Zed Books.

Pye, Lucian W., and Sidney Verba, eds. 1965. Political Culture and Political Development. Princeton: Princeton University Press.

Ram, Mohan. 1989. Sri Lanka: The Fractured State. Delhi: Penguin Books.

Roberts, Michael, ed. 1979. Collective Identities, Nationalisms and Protests in Modern Sri Lanka. Colombo: Margo Institute.

Shlomo, Deshen. 1974. "Political Ethnicity and Cultural Ethnicity in Israel During the 1960s." In Urban Ethnicity, edited by Abner Cohen, 281-310. London: Tavistock.

Spencer, Jonathan. 1990 "Introduction." In Sri Lanka: History and Roots of Conflict, edited by Jonathan Spencer, 1-8. London: Routledge.

Tambiah, S.J. 1986. Sri Lanka: Ethnic Fratricide and the Dismantling of Democracy. Chicago: University of Chicago Press.

Tennekoon, Serena. 1990. "Newspaper Nationalism: Sinhala Identity as Political Discourse." In Sri Lanka: History and Roots of Conflict, edited by Jonathan Spencer, 20526. London: Routledge.

Tudor, Henry. 1972. Political Myth. London:Pall Mall.

Wilson, A. Jeyaratnam. 1982. “Sri Lanka and its Future: Sinhalese and Tamils." In The States of South Asia: The Problems of National Integration, edited by A.J. Wilson and D. Dalton, 295-312. New Delhi: Vikas. - 1988. The Break-Up of Sri Lanka: The Sinhalese Tamil Conflict. London: C. Hurst.

Wuthnow, Robert. 1987. Meaning and Moral Order: Explorations in Cultural Analysis. Berkeley: University of California.

Wuthnow, Robert, and Marsha Witten. 1988. "New Directions in the Exploration of Culture.". Annual Review of Sociology 14: 4967.

Young, Crawford. 1976. The Politics of Cultural Pluralism. Madison: The University of Wisconsin Press. 